\title{
Consumer awareness toward remanufactured parts and components: the case of the automotive industry in Sarawak.
}

\author{
Martha Mat*1 and Rashidah Kamarulzaman ${ }^{2}$ \\ ${ }^{1,2}$ Department of Marketing, School of Business and Management \\ University of Technology Sarawak \\ No. 1, Jalan Universiti, 96000 Sibu, \\ Sarawak, Malaysia. \\ *Corresponding author: mbm19090001@ student.ucts.edu.my
}

\begin{abstract}
The growth of the automotive industry in Sarawak although slow compared to other countries, but it is continuously particularly in remanufacturing sector that produces remanufactured parts and components. The main objective of conducting this study is to determine the influencing factor that influences consumer awareness toward remanufactured parts and components for the automotive industry in Sarawak. The independent variable for the study are education, policy, marketing strategy, and social influence, while the dependent variables for this study are consumer awareness toward remanufactured parts and components for the automotive industry in Sarawak. This research is aim to examine whether the influencing factor will give any effect toward the level of consumer awareness toward automotive remanufactured product in Sarawak. This research uses a qualitative approach. The qualitative approach that this study is using an in-depth interview method. A total of five companies and a total of five respondent was interviewed. This respondent consists of people that come from a company doing the remanufacturing process on automotive parts and components. The sample location for this research is in Sarawak only. The collected data from the interview are analyses using Atlas.ti. The findings show that most of the consumers of the companies have for remanufacturing sector are consumer that own business. Four out of five of the respondents claimed that they use Word of Mouth as their marketing strategy. Lastly, all of the respondents stated that they did not receive any kind of support or incentive from any government and non-government body. Therefore, it is shown that marketing strategy and social influence have influence consumer awareness toward remanufactured parts and components for the automotive industry. This study can assist policymakers to improve current policy, assist industry players to upgrade their marketing strategies, and provide useful literature material for the future researcher.
\end{abstract}

Keywords: Consumer Awareness, Remanufactured Parts and Components, Automotive Industry

\section{Introduction}

The demand for remanufactured product does exist, but up until now, it is still lower than in other industries. It all began when World War II broke out in 1939. Natural resources were quite limited during wartime, causing most of the resources were being used for war efforts such as ships, tanks, weapons, and planes. This has resulted in the birth of this remanufacturing industry. Many companies have already been involved in 


Submitted: 07 August $2021 \quad$ Accepted: 18 October $2021 \quad$ Published: 31 December 2021
remanufacturing the vehicle for a long time. Remanufactured parts are described as having a function that is at least equivalent to that of the original part, according to the Automotive Parts Remanufacturers Association (APRA) Europe. It's manufactured from a pre-existing part (CORE) that's been recovered using standardized manufacturing techniques that meet stringent technical requirements. According to APRA Europe (2020), a remanufactured product has the same warranty as a new part and is clearly marked as such with the name of the remanufacturer.

The National Automotive Policy (NAP) in Malaysia was first introduced in 2006 under the Third Industrial Masterplan (IMP3) 2006-2020, which is to facilitate the integration of the local automotive industry to regional and global levels. In 2009, the policy was reviewed to focus on enhancing the capabilities of the domestic automotive industry and create a more conducive environment for investments. The second revision in 2014, named NAP 2014 emphasized green initiatives, market expansion, thorough enhancement of the entire automotive ecosystem, and development of technology, human capital, and supply chain (MARii, 2019). In 2020, Malaysia's former Prime Minister officially launched the NAP 2020. According to the former Prime Minister, the latest NAP will use three strategies. The first strategy is value chain development, the second strategy is human capital development, and the third strategy is safety, environment, and consumerism. (Shankar, 2020). The latest NAP did mention to improve, enhance, and promoting remanufacturing in its planning. Remanufacturing has been included in both NAP 2020 vision, strategies, and roadmap (MITI, 2020) in hope that this industry will thrive in the future.

In Malaysia, there are automotive companies registered under 4R2S that practise remanufacturing in their company stated by Malaysia Public Sector Open Data Portal (2018). 4R2S stands for 4R (Repair, Reuse, Recycle and Remanufacture) and 2S (Service and Spare Parts) Industry Standards, develop by Malaysia Automotive, Robotics and IoT Institute (MARii) assisted by SIRIM Berhad. 4R2S is the Malaysia standard for qualification and standardization of automotive parts and components for the Reuse, Recycle, Remanufacturing, Repair, and Services programs, under a transformation program for the aftermarket. The standards serve as a guideline for industry businesses that provide the $4 \mathrm{R}$ and workshop services. As for now, there are a total of 34 companies that practice remanufacturing with 22 companies focus on vehicle rebuilt only still operating in Malaysia, and the 4R2S standard has changed and upgraded its title to 4R2S MS (Malaysia Standard) with the same content. Although the NAP has been introduced in 2006 and National Remanufacturing Policy has already been approved by the cabinet on 18 December 2019, consumer awareness regarding the automotive remanufactured part is still low.

Consumer awareness, which refers to a buyer's knowledge of a particular product or company, allows the buyer to get the most from their purchases. Consumers can make well-informed choices about what to buy and how much to spend when they have product information (Thomas, 2018). Information regarding the remanufactured product is still low but still very important.

\section{Research Problem}

The demand for remanufacturing products in the market is there, but the availability of the product is still inadequate. In Malaysia, remanufacturing has just begun in 2019 and exhibit a promising future potential in the automotive industry. But Malaysia is still 

sector. According to the Deputy Ministry of Trade and Industry (MITI) on 18 January 2019 while briefing the media on the automotive sector outlook for 2019, he explained that the government is going to announce a national remanufacturing policy soon.

To stimulate the automotive industry in Malaysia, the National Automotive Policy (NAP) has been developed since 2006. Since then, NAP has been reviewed for few times to make sure the NAP is always up to date. In the beginning, NAP's main objective is to increase the competition among regional and global automotive industry networks. When NAP was reviewed in 2009 , its objective was to enhance the capability and competitiveness of the domestic automotive industry. The NAP was reviewed in 2014 is more focused on the green initiative, development of technology, human capital, market development, and automotive industry ecosystem enhancement. The policy on the automotive remanufacturing industry is finally launched on 21 February 2020 which focuses on three strategies which are value chain development, human capital development and safety, environment and consumerism. This policy will enhance Malaysia's automotive industry in the era of digital industrial transformation.

Remanufacturing failures are due to market size, pricing, consumer perception, inefficient marketing strategy in the remanufacturing sector, and information failures. According to Varadarajan (2015), a marketing strategy is an organization's integrated pattern of decisions that specify its crucial choices concerning products, markets, marketing activities, and marketing resources in the creation, communication, or delivery of products that offer value to consumers in exchanges with the organisation and thereby enable the organization to achieve specific objectives. Value proposition, information of target consumer, key marketing messages, and other important elements are the contents inside the company marketing strategy. But somehow, remanufacturing fail in their marketing strategy.

This research aims to examine the factor that influences consumer awareness toward automotive remanufactured products in Malaysia. The influencing factor will be policy, education, marketing, and social influence. Other than that, this research will examine the level of consumer awareness of the automotive remanufactured product in Malaysia.

\section{Literature Review}

\section{Consumer Awareness}

Consumer awareness is a knowledge that consumer has regarding a product or serviced that they have purchased. According to Thomas (2018), consumer awareness is referred as consumer knowledge regarding a specific product or a firm which help consumer to get most from their purchases. With that knowledge, consumers can make the right choice when making a purchase and how much to spend when they have the product information. Consumer awareness is a basic thing for a consumer to know about a remanufactured product even know that remanufacturing industry in Malaysia is still new, (Mohamed, Saman, Sharif, \& Hamzah 2018).

\section{Policy}



their government has taken some action to construct regulations regarding remanufacturing due to the increased awareness toward the environment. This regulation somehow can give positive or negative effects on the remanufacturing sector. (Subramoniam, et al, 2009). As climate change obtain attention, environmentally friendly kind of manufacturing such as remanufacturing would as well be increased. In the meantime, companies have to concentrate on economic advantages with proper equipment and preparation.

\section{Education}

Consumer awareness and rational usage can be identified through education. In the literature on consumer behavior, product awareness is frequently undervalued. Having awareness of a product means having knowledge or information about the product or subject. This is when education comes into play. Aside from fostering economic progress, education can help society develop high-level knowledge (Singh, 2013).

\section{Marketing}

When talking about the remanufactured product, a topic that will discuss usually regarding the process and operation management. But marketing focus has always been ignored. But according to Vogtlander, Scheepens, Bocken, and Peck (2017), a remanufactured product marketing strategy is depending on the combination of a characteristic of the product itself such as the quality of the product and the lifespan of the product itself. Remanufacturing industry can help the automotive industry generate more income in an environment-friendly and sustainable approach while fulfilling their Corporate Social Responsibility (CSR).

\section{Social Influence}

Social influence can aid in the promotion of a product. When a person is influenced by someone else beliefs, feelings, or behaviors, this is known as social influence. When an influencer, such as a famous celebrity, a family member, a friend, a coworker, or a stranger, shares their experience with a remanufactured product, their listeners may be influenced to either aware or purchase that product. Smith, Louis, and Schultz (2011) stated that conformity, social development, peer group, compliance, leadership, manipulation, minority influences, and social change processes are all examples of social influence. It is a huge aspect of how people engage with one another and within organizations.

\section{Behavioral Intention}

Changes in behavioral intention can be a significant factor since they can lead to a person accepting new practices, routines, technology, environment, products, and services. A sign on which factor can impact a person's decision to be performed could be a behavioral intention that can be controlled by an individual. Behavioral intention, according to Ajzen (2015), is a motivator that determines how much a person wants or is willing to engage in a particular behavior. A strong and stable factor may lead to a person's willingness to take specified action.

\section{Underlying Theory}




Submitted: 07 August $2021 \quad$ Accepted: 18 October 2021 $\quad$ Published: 31 December 2021

The underlying theory will outline which theory developed by researchers in the past that was used as the underlying theory. The theory will aid this study in determining the proper variables to apply and the research's direction. This study using Theory of Planned Behavior as underlying theory. Policy, education, marketing, and social influence are the paper's independent variables. The dependent variables in this paper are customer awareness of remanufactured products. While the mediator variable will be behavioral intention. According to figure 1, the research used social influence, behavioral intention, and customer awareness as research variables, which were adapted and adjusted from previous research, Ajzen (1991).

\section{Theory of Planned Behavior (TPB)}

Icek Ajzen established the Theory of Planned behavior (TPB) in 1985. TPB is the direct antecedent of the person 's desire to conduct the specific behavior in situation. TPB is a social-psychological theory that elucidates a person behavioral decision-making processes with the intention of identifying and deciding a person behavior, encouraging the notion that a person successful completion of a behavior is mainly controlled by a person will (Ajzen \& Fishbein, 1975).

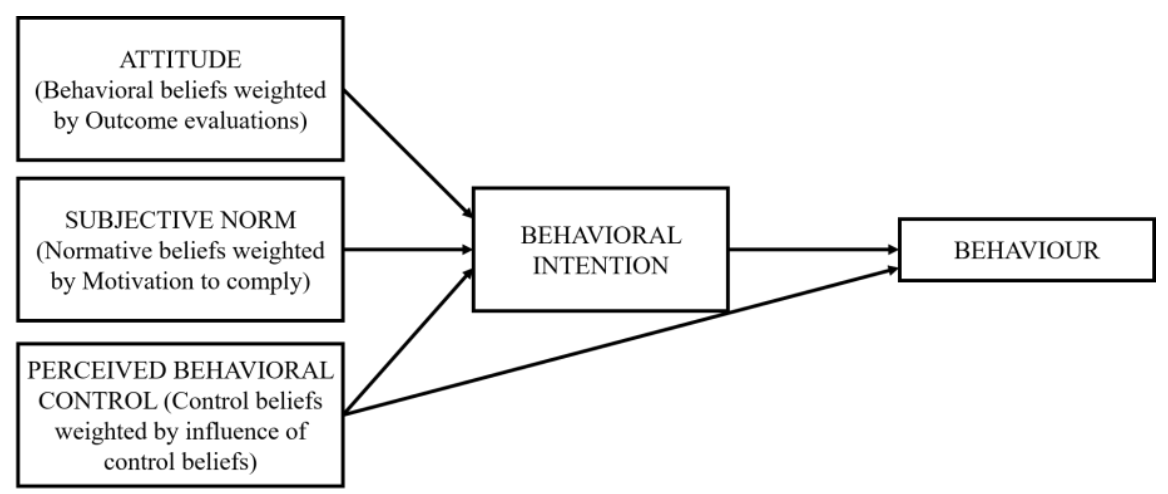

Figure 1: Theory of Planned Behavior

Sources: Icek Ajzen (1975)

\section{Methodology}

The qualitative method is used as a data collection method for this research. The method that is used is an in-depth interview. The interview was conducted with the expertise of the automotive industry in Sarawak that practicing remanufacturing in their company. The respondents for the interview comprised the company's CEO, marketing strategist, and top management. There is five company that have been interviewed for this research is based at Sarawak. The interview questions used for the interview ware derived from a focus group session that was held in early December 2019. Data that has been collected from each company are analysed using Atlas.Ti.

\section{Sampling Procedure}

The sample size for this research is five people. These respondents come from a company that is involved in remanufacturing activity in Sarawak either directly or 
indirectly, hence, becomes the main factor of the reason for their selection. The respondent is all based on Sarawak.

\section{Data analysis}

After the interview was conducted between all the five companies, the data that was gathered from the interview are analyses using computer software, Atlas.ti. Atlas.ti is computer software, a sophisticated platform for analyzing massive amounts of text, visual, audio, and video data qualitatively. It is an advanced tool that assists the researcher in organizing, reconstructing, and handling the resources in an inventive yet logical manner. Atlas.ti helps researchers stay focused on the content of the data (Atlas.ti, 2021).

\section{Findings}

\section{Remanufacturing Situation}

The remanufacturing sector in the automotive industry is implemented as one way to encourage industry players in Malaysia to shift from rebuilt. In the interview, company A which is based in Sarawak that practice remanufacturing, has been established for 47 years. For now, the problem that they are facing is in terms of location. They have been relocated three times because of floods in the area where they operated their business. The components that they use for remanufacturing are mostly comes from Japan. Previously, they imported from England for a short-limited time. However, they plan to import from England again in the future. Meanwhile Company B has been established for more than 65 years. The company claimed that their business is okay at the moment. For Company $\mathrm{C}$, according to the interview with the company, most of their part is imported from Japan but remanufacture in Malaysia. Company $\mathrm{C}$ stated that in general, the consumer only knows two types of parts, either repaired or new. Remanufacture is the third option which is not mainstream yet to their consumer. From the interview, the study found out that company D does not produce remanufactured products anymore. They stop doing remanufacturing slowly since 2015 due to both reasons of bad location and lack of resources. The last company that was interviewed is company E. Company E start rebuilt activity in 2003. They said that their company remanufactures both domestic components and OEM components but between domestic and OEM components, OEM components have higher demand due to their branding and popularity.

\section{Consumer of Remanufacture}

Consumer is one of important elements in business in any industry. For that reason, it is important for business to take note of who their consumers are and what provoke their consumer to make a purchase. According to the interview, Company A regular consumer is their CEO close friend, which is mostly consumer that own business come from plantation background and seldom have an individual consumer. The reason why the consumers are attracted to buy their remanufactured product is because the price is not expensive. For Company B consumer consists of consumer own business in plantation and not an individual consumer. The reason their consumer purchased their remanufactured product is because the price is not expensive and the brand is well known as they import parts to be remanufactured from Japan. A brand like Suzuki and Daihatsu are very well known in remanufacturing industry. Meanwhile, Company $\mathrm{C}$ 


Submitted: 07 August $2021 \quad$ Accepted: 18 October $2021 \quad$ Published: 31 December 2021
consumer is usually consumer that own a business that already know their company from various background such as steel industry, transportation, agriculture, forwarding, mining and quarry and recycling industry too. They rarely have an individual as their consumer, a few but very rare. Most of the time, their consumers purchase remanufactured products because the price is affordable and sometimes, they give discounted prices to their return consumers. Apart from that, their consumers also considered the product's reliability, which is in their mindset, depending on the product brand. However, Company D said that most of their consumers are individual consumer and just a few consumers from business background as their consumer. When purchasing a remanufactured product from their company, the consumer will look at two factors which are the price and the condition of the remanufactured product. Lastly, Company E stated that most of their consumer according to them are small and mediumsized enterprises (SMEs) within Malaysia's core business in plantation, transportation, construction, and mining. Their consumer always looks at the price and the condition of the remanufactured product when purchasing them.

\section{Marketing Strategy of Remanufacture}

In order to attract and engage with consumer in a business especially potential consumer, a marketing strategy is a tool that every company must have. According to the interview, Company A uses Word of mouth as a marketing strategy for their remanufactured product. For Company B, their remanufacturing marketing strategy is word of mouth and regular visits to plantation sites. For Company $\mathrm{C}$, most of the time, their marketing strategy for the remanufactured product is word of mouth which is similar to company A and B. However, company D, during their remanufacturing years, they said that their way to market the remanufactured product is by having a showroom in the city center and sometimes they visit construction sites ask around if the consumer needs any remanufactured component for their truck. Other than that, they even invite people to their company to show their product to the consumer. Lastly, according to interview with company E CEO, to attract and market their remanufactured product to their consumer, they used word of mouth. Other than that, they mention that the company using social media such as creating a Facebook account as part of their marketing strategy.

\section{Support in Remanufacture}

Government has implemented many policies such as NAP and Industry4WRD to support related industry shift to Industry 4.0. However, according to the interview, most of the company does not familiar with certain policy and benefits provided for them. In terms of support from the government or any other parties, company A, B, C, D, and E did not receive any incentive or support from the government or any other parties

\section{Hope for Remanufacture Future}

Although remanufacturing has similarity with rebuilt, the process of changing between these sectors still need to take times and support from all parties. In the interview, when ask about their hope in remanufacturing sector, Company A and B both hope that in the future, the government will provide financial support for them. For Company C, they hope that in the future, the government will provide more incentive to remanufacturing industry, give a clear direction and a chance for them to varied their remanufactured product apart from the truck component. Meanwhile, according to Company D, although 

provided financial support to remanufacturing industry. Company $\mathrm{E}$ also hopes the same thing as previous companies which is to have government support in terms of finances in the future.

\section{Implication}

This research can assist policymakers in either developing better policies or improving existing policies that fit nowadays modern age. The research demonstrated the need of the consumer in the automotive industry and the factor that influence them in acknowledging the remanufactured products. This research can become the base for the policymaker. According to Torjman (2005), a policy was set up to solve a problem and fill the need of society. Policy exists when there is a need for and was a demand by society. This is to avoid a company in the industry divert from the course that has been layout in the guidelines.

Aside from that, this research may aid future scholars in remanufacturing marketing-related themes. This research can benefit both the reader and the researcher. There is currently a scarcity of information and education about the remanufacturing sector in social science. The majority of it focuses on the process and design of the remanufacture product. As a result, this research could provide information on the remanufacturing sector and add knowledge to the literature on the remanufacturing sector.

When compared to other industries, the remanufacturing sector is more complex. Hence, this research aids industry players in the automotive industry in enhancing marketing strategies for their remanufacturing businesses. Not only the government, but everyone associated in the remanufacturing sector, has a responsibility to undertake in educating consumers about sustainable manufacturing or remanufacturing. Several forms of study were conducted, according to Govindan et al (2019), to address the issue of consumer perception of remanufactured product quality. Strategies such as incentives and awareness education are part of the solution. This demonstrates how crucial it is to meticulously plan and improve a marketing strategy in order to attract and keep customers.

\section{Conclusion}

Malaysia's government has implemented a program to support remanufacturing sector, but the public awareness towards the remanufacturing product is still low. But, the remanufacturing sector in the automotive industry awareness among consumers in Sarawak is still lacking. It is important to exposed knowledge regarding remanufactured parts and components of the automotive industry to consumers. It is important to know the level of knowledge or awareness about remanufacturing in automotive among the consumer to make sure consumers understand the concept for them to accept the remanufactured product. For that reason, it is important to know the level of consumer awareness in remanufacturing industry for the industry player to provide the right knowledge and also to attract consumers to purchase their remanufactured parts and components for the automotive industry. The existed marketing strategy that remanufacturing sector currently used is not effective. With a suitable marketing strategy, it can help remanufacturing sector for the automotive industry in Sarawak 

growth. Currently, the automotive remanufacturing industry is largely to cater to the needs of the industry consumers. Thus, the strategy that is widely used among the remanufacturing organizations is more towards the word of mouth without massive usage of the digital medium. To cater to the individual users, an overhaul of the marketing strategy of the remanufacturing organizations needs to be done. In a conclusion, the remanufacturing sector in Sarawak can grow further not only to attract local but also international consumers. This requires cooperation from the consumer, the industry player, and the government for it to happen.

\section{Acknowledgement}

This study is fully funded by Malaysia Automotive Robotic and IoT Institute (MARii).

\section{References}

Ajzen, I. (1991). The theory of planned behavior. Organizational behavior and human decision processes, 50(2), 179-211.

Ajzen, I. (2015). Consumer attitudes and behavior: the theory of planned behavior applied to food consumption decisions. Italian Review of Agricultural Economics, 70(2), 121-138.

Atlas.ti (2021). What is Atlas.ti. Retrieved from https://atlasti.com/product/what-isatlas-ti/.

Automotive Parts Remanufactures Association (APRA) Europe (2020). The Voice of Remanufacturing Since 1941 [Flyer]. Retrieved from https://apraeurope.org/wpcontent/uploads/2021/03/APRA-Europe_Flyer_2020_EN.pdf.

Fishbein, M. \& Ajzen, I. (1975). Belief, attitude, intention, and behaviour: An introduction to theory and research. Reading, Mass.: Addison - Wesley.

Govindan, K., Jiménez-Parra, B., Rubio, S., \& Vicente-Molina, M.A. (2019). Marketing issues for remanufactured products. Journal of Cleaner Production, 227, 890899.

Malaysia Automotive Robotic and IoT Institute (MARII). (2019). The Automotive Industry: The History. Retrieved from http://www.marii.my/automotive.

Malaysia's Open Data Portal. (2018). REMAN companies registered under 4R2S. Retrieved from http://www.data.gov.my/data/en_US/dataset/list-of-remancompanies-registered-under-4r2s.

Ministry of International Trade and Industry. (2020). National Automotive Policy 2020 - MITI. Retrieved from https://www.miti.gov.my > NAP2020_Booklet.

Mohamed, N, Saman, M.Z.M., Sharif, S., \& Hamzah, H.S. (2018). Strategic Factors on Interpreting Remanufacturing Quality-Certifying Framework to Address Warranty Aftermarket for Malaysian Industry. IOP Conference Se.

Shankar, A.C. (2020). NAP 2020 to use three strategies. Retrieved from https://www.theedgemarkets.com/article/nap-2020-use-three-strategies.

Singh, J.D. (2013). Role of education in knowledge-based society. Recommendations of National Knowledge Commission: Directions for Implementation, 29-34.

Smith, J.R., Louis, W.R., \& Schultz, P.W. (2011). Introduction: Social influence in action. Group Processes \& Intergroup Relations, 14(5), 599-603. 
Submitted: 07 August 2021 Accepted: 18 October 2021

Published: 31 December 2021

Subramoniam, R., Huisingh, D., \& Babu, R. (2009). Remanufacturing for the automotive aftermarket-strategic factors: literature review and future research needs. Journal of Cleaner Production, 17(13), 1163-1174.

Thomas. J. (2018). What is the Meaning of Consumer?. Retrieved from https://legalbeagle.com/6137961-meaning-consumer-awareness.html.

Torjman, S. (2005). What is Policy? Ottawa: The Caledon Institute of Social Policy.

Varadarajan, R. (2015). Strategic marketing, marketing strategy and market strategy. AMS Review, 5(3-4).

Vogtlander, J.G., Scheepens, A.E., Bocken, N.M.P., \& Peck, D. (2017). Combined analyses of costs, market value and eco-costs in circular business models: ecoefficient value creation in remanufacturing, 1-17. 